\title{
The Use of Eosinophil Count in Predicting the Need of Coronavirus Disease 2019 Patient for Treatment in Intensive Care Unit
}

\author{
Ngakan Ketut Wira Suastika*(iD, Ketut Suega D \\ Department of Internal Medicine, Faculty of Medicine, Udayana University, Udayana University Hospital, Bali, Indonesia
}

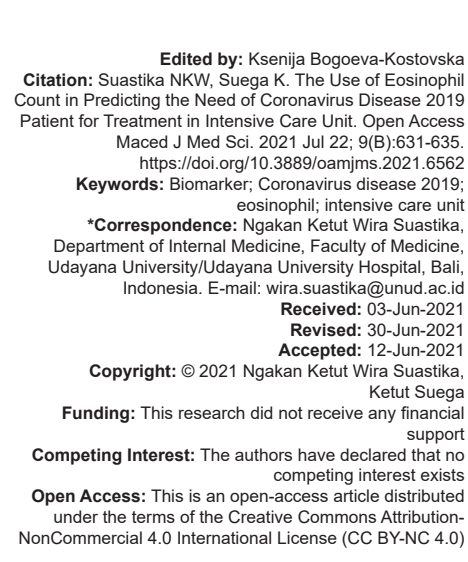

Introduction

Coronavirus disease 2019 (COVID-19) caused by severe acute respiratory syndrome coronavirus 2 (SARS-CoV-2) has infected more than 152 million people worldwide with more than 3 million deaths (data until May 3, 2021) [1]. The highest number of confirmed cases of COVID-19 occurred in the European and American regions [2]. The incidence of acute respiratory distress syndrome (ARDS) is quite high, between $17 \%$ and $29 \%$ of hospitalized COVID19 patients [3], [4], [5]. Critical patients with ARDS require treatment in the intensive care unit (ICU). The mortality rate during 28 days of treatment in the ICU was very high, reaching $62 \%$ [6]. The relatively high number of critical cases in COVID-19 is a problem, especially in health facilities with a limited number of ICU [7], [8]. A biomarker is needed that can be used for risk stratification or early identification of patients who have the potential for worsening clinical conditions so that aggressive therapy can be given from the early of treatment.

Several inflammatory biomarkers such as ferritin [9], C-reactive protein (CRP) [10], and some cytokines [11] are associated with disease severity in
COVID-19. However, examining these inflammatory markers is time consuming and expensive. During this pandemic, biomarkers that provide fast and costeffective results are needed. Eosinophil count is a potential biomarker for assessing disease progression in COVID-19. Studies show that there is a decrease in circulating eosinophils in some viral infections such as respiratory syncytial virus (RSV) pneumonia [12]. Experimental studies on mice infected with RSV and influenza have shown that eosinophils play a role in virus defense and are also responsible for organ damage due to the release of mediators [13], [14]. Eosinophils and neutrophils are also inflammatory cells that infiltrate the lungs in Middle East respiratory syndrome coronavirus infection [15].

In COVID-19 patients, eosinopenia is found in $47-66 \%$ of cases [16], [17]. A study by Xie et al. found that patients with low eosinophil counts had more complaints of fever and shortness of breath, worse chest radiology, and longer length of stay compared to normal eosinophil counts [18]. There are many studies on the role of lymphocytes and neutrophils, but few studies on the role and diagnostic value of eosinophils in COVID-19.

This study aims to determine the diagnostic value and differences of eosinophil counts in patients 
with COVID-19 who require treatment in ICU and non-ICU.

\section{Methods}

\section{Study design and sample}

This prospective study was conducted on 382 patients who were treated at the Udayana University Hospital, Bali, Indonesia, from May 2020 to September 2020. Inclusion criteria were patients over 18 years of age who were confirmed COVID-19 through nasopharyngeal swab examination with the realtime reverse-transcriptase polymerase chain reaction method. Patients who had received steroid or antihistamine therapy before admission to the hospital, patients with a history of allergies, and patients who died within $24 \mathrm{~h}$ of treatment were excluded from the study.

The criteria for patients who need treatment in the ICU are patients with critical criteria according to the World Health Organization interim guidelines, including (1) patients with severe ARDS $\left(\mathrm{PaO}_{2} / \mathrm{FiO}_{2} \leq 100 \mathrm{mmHg}\right)$ or need mechanical ventilation; (2) patients with sepsis characterized by impaired organ function, including decreased consciousness, decreased urine output, or acidosis; and (3) patients with septic shock (persistent hypotension even with fluid resuscitation, and requiring a vasopressor to maintain a mean arterial pressure $\geq 65 \mathrm{mmHg}$ ) [19].

This study protocol has received approval from the Institutional Review Board of the Faculty of Medicine, Udayana University (1010/UN1422.VII.14/LT/2020).

\section{Data collection and instruments}

Epidemiological, clinical characteristics (symptoms and signs, history of medication, and allergy), and laboratory data were obtained from patient medical records. Blood samples for laboratory examinations including a complete blood count are taken when the patient is admitted to the hospital. Patients were followed during hospitalization and recorded whether requiring treatment in the ICU or remaining in the general ward (non-ICU).

To detect SARS-CoV-2 from nasopharyngeal swab samples, Roche Diagnostic SARS-CoV-2 test was used. The absolute and percentage eosinophil count was obtained from a complete blood count that was checked with the Sysmex XN-series automated hematology analyzer.

\section{Data analysis}

Continuous variables are described into the median (interquartile ranges [IQRs]) while categorical variables are described as percentages. To compare continuous variables, Mann-Whitney U-test analysis was used, while for categorical variables, we used Chisquare analysis.

Analysis using the receiveroperating characteristic curve was used to obtain the area under the curve (AUC), sensitivity and specificity of the absolute and percentage eosinophil count to predict the need of COVID-19 patients for treatment in ICU. Eosinophil count variables and age were transformed into dichotomous variables based on the best cutoff values that had been found. To determine the effect of confounding variables, multivariate logistic regression analysis was used. All statistical analyzes used SPSS version 25.0 software. The results obtained were statistically significant if $p<0.05$.

\section{Results}

\section{Epidemiological, clinical characteristics, and complete blood count}

Of the 382 patients, 31 patients $(8.1 \%)$ required treatment in the ICU. The median age of the patients was 46 years (IQR 18-84 years). Most of the sample (63\%) are male. A total of 97 (25.4\%) patients had various comorbidities, mostly diabetes (44.3\%) (Table 1). The absolute and percentage eosinophil counts were significantly lower in patients who require treatment in the ICU compared to non-ICU ( $p<0.001)$. There are also significant differences in age, comorbidities, hemoglobin level, hematocrit, leukocyte, neutrophil, lymphocyte, and monocyte counts, however, there were no significant differences in sex and platelet counts in the two groups.

\section{Eosinophil count to predict of patient need for treatment in the ICU}

The percentage of eosinophil counts had a slightly better diagnostic value than the absolute eosinophil count. The area under curve of absolute and percentage eosinophil counts is $0.659(95 \% \mathrm{Cl} 0.503$ $0.816)$ and $0.738(95 \% \mathrm{Cl} 0.611-0.865)$, respectively. The best cutoff values obtained are: $<0.025 \times 10^{3} \mu \mathrm{L}$ for the absolute eosinophil count with a sensitivity of $77.7 \%$ and a specificity of $50.0 \% ;<0.25 \%$ for the percentage eosinophil counts with a sensitivity of $78.3 \%$ and a specificity of $57.1 \%$ (Figure 1 and Table 2).

\section{Association between eosinophil counts with the patient need for treatment in the ICU}

Multiple logistic regression analysis was used to determine the effect of age and comorbidity variables. We found that the percentage eosinophil count was independently associated with the need 
Table 1: Epidemiological characteristics, eosinophil count, and other complete blood count parameters

\begin{tabular}{|c|c|c|c|c|}
\hline \multirow[t]{2}{*}{ Variable } & \multicolumn{4}{|c|}{ Median (interquartile range) } \\
\hline & All patients $(n=382)$ & Non-ICU $(n=351)$ & $\operatorname{ICU}(\mathrm{n}=31)$ & $p$ value \\
\hline Age, years & $46(18-84)$ & $44(18-84)$ & $57(32-75)$ & $<0.001$ \\
\hline \multicolumn{5}{|l|}{ Sex, n (\%) } \\
\hline Male & $244(63.9)$ & $222(63.2)$ & $22(71.0)$ & \multirow[t]{2}{*}{0.508} \\
\hline Female & $138(36.1)$ & $129(36.8)$ & $9(29.0)$ & \\
\hline \multicolumn{5}{|l|}{ Comorbidities, n (\%) } \\
\hline Without comorbidities & $285(74.6)$ & $274(78.1)$ & $11(35.5)$ & \multirow[t]{8}{*}{$<0.001$} \\
\hline With comorbidities & $97(25.4)$ & $77(21.9)$ & $20(64.5)$ & \\
\hline Hypertension & $27(27.9)$ & $23(29.9)$ & $4(20.0)$ & \\
\hline Diabetes & $43(44.3)$ & $31(40.2)$ & $12(60.0)$ & \\
\hline Congestive heart failure & $9(9.3)$ & $7(9.1)$ & $2(10.0)$ & \\
\hline Coronary artery disease & $11(11.3)$ & $11(14.3)$ & $0(0)$ & \\
\hline Asthma & $4(4.1)$ & $3(3.9)$ & $1(5.0)$ & \\
\hline Chronic kidney disease & $3(3.1)$ & $2(2.6)$ & $1(5.0)$ & \\
\hline Hemoglobin, gr/dl & $13.9(7.9-17.4)$ & $13.9(8.9-17.4)$ & $13.1(7.9-16.0)$ & 0.028 \\
\hline Hematocrit, \% & $40.7(24.2-50.2)$ & $41.0(24.2-50.2)$ & $39.0(32.9-47.2)$ & 0.035 \\
\hline Leukocyte, $\times 10^{3} \mu \mathrm{L}$ & $6.79(2.36-17.25)$ & $6.72(2.36-15.98)$ & $7.67(3.87-17.25)$ & 0.008 \\
\hline \multicolumn{5}{|l|}{ Eosinophils } \\
\hline Absolute, $\times 10^{3} \mu \mathrm{L}$ & $0.09(0.00-1.53)$ & $0.09(0.0-1.53)$ & $0.02(0.0-0.1)$ & $<0.001$ \\
\hline Percent, \% & $1.2(0.0-12.0)$ & $1.4(0.0-12.0)$ & $0.2(0.0-3.1)$ & $<0.001$ \\
\hline \multicolumn{5}{|l|}{ Basophils } \\
\hline Absolute, $\times 10^{3} \mu \mathrm{L}$ & $0.01(0.00-1.00)$ & $0.01(0.0-1.0)$ & $0.01(0.0-0.1)$ & 0.02 \\
\hline Percent, \% & $0.2(0.0-8.01)$ & $0.2(0.0-8.01)$ & $0.1(0.0-0.4)$ & $<0.001$ \\
\hline \multicolumn{5}{|l|}{ Neutrophil } \\
\hline Absolute, $\times 10^{3} \mu \mathrm{L}$ & $4.2(0.99-15.50)$ & $3.99(0.99-13.78)$ & $6.38(2.78-15.50)$ & $<0.001$ \\
\hline Percent, \% & $62.55(0.2-95.2)$ & $61.3(33.9-93.5)$ & $81.6(67.3-95.2)$ & $<0.001$ \\
\hline \multicolumn{5}{|l|}{ Lymphocyte } \\
\hline Absolute, $\times 10^{3} \mu \mathrm{L}$ & $1.55(0.31-5.92)$ & $1.61(0.31-5.92)$ & $0.82(0.31-5.70)$ & $<0.001$ \\
\hline Percent, \% & $24.9(1.29-53.6)$ & $26.2(1.4-53.6)$ & $10.0(1.29-24.0)$ & $<0.001$ \\
\hline \multicolumn{5}{|l|}{ Monocyte } \\
\hline Absolute, $\times 10^{3} \mu \mathrm{L}$ & $0.58(0.05-1.66)$ & $0.58(0.09-1.66)$ & $0.46(0.05-1.33)$ & 0.017 \\
\hline Percent, \% & $8.9(0.7-25.0)$ & $9.1(0.7-25.0)$ & $6.4(0.7-14.2)$ & $<0.001$ \\
\hline Platelet, $\times 10^{3} \mu \mathrm{L}$ & $241.5(54-672)$ & $242(54-672)$ & $224(92-579)$ & 0.45 \\
\hline
\end{tabular}

Table 2: The cutoff value, sensitivity, specificity, and AUC of eosinophils count

\begin{tabular}{lllllll}
\hline Variable & $\begin{array}{l}\text { Cutoff } \\
\text { value }\end{array}$ & $\begin{array}{l}\text { Sensitivity } \\
(\%)\end{array}$ & $\begin{array}{l}\text { Specificity } \\
(\%)\end{array}$ & AUC & $95 \% \mathrm{Cl}$ & p value \\
\hline Absolute eosinophils & $<0.025$ & 77.7 & 50.0 & 0.659 & $0.503-0.816$ & 0.043 \\
Percent eosinophils & $<0.25$ & 78.3 & 57.1 & 0.738 & $0.611-0.865$ & 0.003 \\
\hline
\end{tabular}

for COVID-19 patients for treatment in the ICU with an adjusted odds ratio (OR) of 3.31 (95\% confidence interval [Cl] 1.34-8.13), $\mathrm{p}=0.009$ (Table 3).

Table 3: The OR and adjusted OR of percentage eosinophils count, comorbid, and age

\begin{tabular}{lllll}
\hline Variable & $\begin{array}{l}\text { Odds ratio }(95 \% \\
\mathrm{Cl})\end{array}$ & $\mathrm{p}$ & $\begin{array}{l}\text { Adjusted odds } \\
\text { ratio }(95 \% \mathrm{Cl})\end{array}$ & $\mathrm{p}$ value \\
\hline Percentage eosinophils count & $4.79(2.25-10.18)$ & $<0.001$ & $3.31(1.34-8.13)$ & 0.009 \\
Comorbidities & $6.69(3.07-11.04)$ & $<0.001$ & $3.85(1.56-9.52)$ & 0.003 \\
Age & $3.65(1.53-8.69)$ & 0.004 & $1.53(0.56-4.16)$ & 0.409 \\
\hline
\end{tabular}

\section{Discussion}

Our study found significant differences in eosinophil counts in COVID-19 patients who need treatment in the ICU compared to non-ICU. This result is consistent with the study of Yan et al. who found that the eosinophils count was significantly lower in critical cases compared to moderate-severe cases. This study also found that the eosinophil count correlated with levels of D-dimer, urea, serum creatinine, serumaminotransferase, and lactate dehydrogenase [20]. Another study showed that eosinophil counts increased gradually, according to improve chest computerized tomography scans [18]. The eosinophil count was found to have decreased significantly in COVID-19 and returned to normal levels

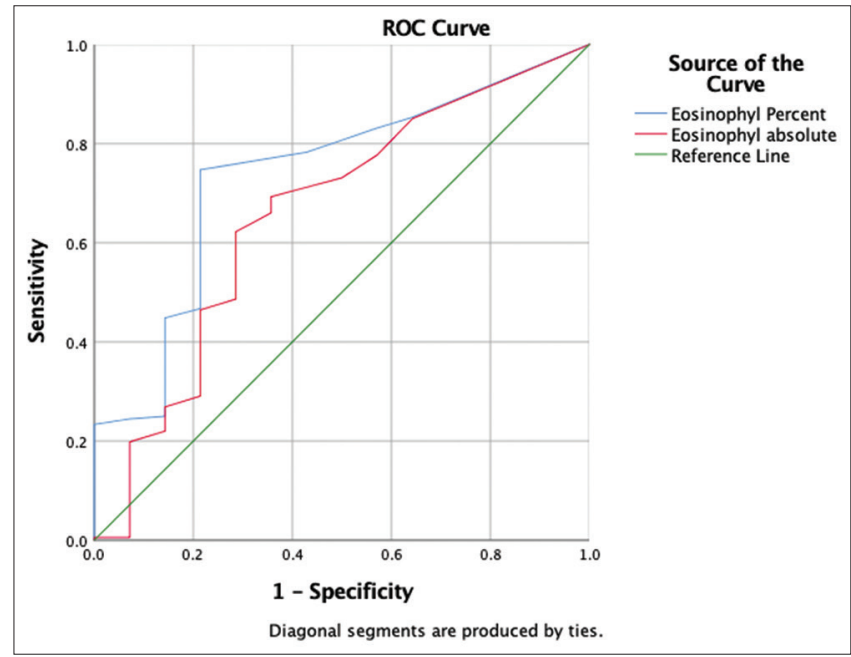

Figure 1: The ROC curve of absolute and percentage eosinophil counts to predict the need of Covid-19 patients for treatment in ICU

gradually according to the improvement in the patient's condition, whereas, in patients with clinical deterioration, the eosinophil count continued to decline [21].

Our study found that the percentage eosinophil count has a better diagnostic value than the absolute eosinophil count. This can occur because the number of eosinophils relative to total white blood cells reflects the status of inflammation that occurs in COVID-19. Neutrophils will be recruited into the lungs in large numbers, followed by a shift with an increase in neutrophil production and a decrease in eosinophil production in the bone marrow [18]. Studies show that eosinophils and neutrophils are recruited into lung tissue starting in the early phase of viral infection and before the onset of respiratory symptoms [22]. Increased production of proinflammatory cytokines and decreased production of 
anti-inflammatory cytokines will cause a large number of neutrophils, lymphocytes, and eosinophils infiltrate to the lungs and cause a decrease of eosinophils in peripheral blood [23]. Another mechanism may explain, stress conditions on lung injury causes increased production of corticosteroids by the adrenal glands and causes suppression of eosinophil release by bone marrow [24], [25]. Increased corticosteroids can also lead to decreased differentiation and survival of eosinophils and also stimulate the infiltration of eosinophils into the tissue [25], [26]. The eosinophil count was zero in $61 \%$ of patients who need treatment in the ICU [27]. This phenomenon was also observed in a study by Shaaban et al. in patients with sepsis who were treated in the ICU [28].

Our study found that a percentage eosinophil count $<0.25 \%$ can predict the need of COVID-19 patients for treatment in the ICU with an AUC of more than $70 \%$. Eosinophil counts can be used as a simple and effective biomarker and can be combined with other laboratory parameters for monitoring, evaluation, and predicting the prognosis of COVID-19 patients. Eosinophil counts as a biomarker have several advantages compared to other biomarkers such as D-dimer and CRP, they are cheap and can provide fast results, so they can be used as an option in hospitals with limited resources.

Our study has several limitations. First, examination eosinophil counts only once on admission to the hospital, not to be monitored regularly. Second, this study is a single center with a relatively small number of samples.

\section{Conclusions}

Eosinophil count can be used as a biomarker to predict the needs of COVID-19 patients for treatment in the ICU. Further studies are needed to determine the role of eosinophils in the pathogenesis mechanism of COVID-19 and their potential as therapeutic targets.

\section{Acknowledgments}

The author would like to thank to all management and medical personnel at the Udayana University Hospital, Bali, Indonesia.

\section{References}

1. World Health Organization. WHO Coronavirus Disease 2019 (COVID-19) Dashboard; 2021. Available from: https://www. who.int/emergencies/diseases/novel-coronavirus-2019. [Last accessed on 2021 May 03].

2. Bhattacharya S, Basu P, Poddar S. Changing epidemiology of SARS-CoV in the context of COVID-19 pandemic. J Prev Med Hyg. 2020;61(2):E130-6. https://doi.org/10.2139/ssrn.3722801 PMid:32802995

3. Wang D, Hu B, Hu C, Zhu F, Liu X, Zhang J, et al. Clinical characteristics of 138 hospitalized patients with 2019 novel coronavirus-infected pneumonia in Wuhan, China. JAMA. 2020;323(11):1061-9. https://doi.org/10.1001/jama.2020.1585 PMid:32031570

4. Huang C, Wang Y, Li X, Ren L, Zhao J, Hu Y, et al. Clinical features of patients infected with 2019 novel coronavirus in Wuhan, China. Lancet. 2020;395(10223):497-506. https://doi. org/10.1016/s0140-6736(20)30183-5

PMid:31986264

5. Chen N, Zhou M, Dong X, Qu J, Gong F, Han Y, et al. Epidemiological and clinical characteristics of 99 cases of 2019 novel coronavirus pneumonia in Wuhan, China: A descriptive study. Lancet. 2020;395(10223):507-13. https://doi.org/10.1016/ s0140-6736(20)30211-7

PMid:32007143

6. Yang $\mathrm{X}, \mathrm{Yu} \mathrm{Y}, \mathrm{Xu} \mathrm{J}$, Shu H, Liu H, Wu Y, et al. Clinical course and outcomes of critically ill patients with SARS-CoV-2 pneumonia in Wuhan, China: A single-centered, retrospective, observational study. Lancet Respir Med. 2020;8(5):475-81. https://doi. org/10.1016/s2213-2600(20)30079-5

PMid:32105632

7. Li L, Gong S, Yan J. Covid-19 in China: Ten critical issues for intensive care medicine. Crit Care. 2020;24(124):1-3 https://doi. org/10.1186/s13054-020-02848-Z

PMid:32234064

8. Vergano M, Bertolini G, Giannini A, Gristina GR, Livigni S, Mistraletti $G$, et al. Clinical ethics recommendations for the allocation of intensive care treatments in exceptional, resourcelimited circumstances: The Italian perspective during the COVID-19 epidemic. Crit Care. 2020;24(165):1-3. https://doi. org/10.1186/s13054-020-02891-w PMid:32321562

9. Henry BM, de Oliveira MH, Benoit S, Plebani M, Lippi G. Hematologic, biochemical and immune biomarker abnormalities associated with severe illness and mortality in coronavirus disease 2019 (COVID-19): A meta-analysis. Clin Chem Lab Med. 2020;58(7):1021-8. https://doi.org/10.1515/cclm-2020-0369 PMid:32286245

10. Tan C, Huang Y, Shi F, Tan K, Ma Q, Chen Y, et al. C-reactive protein correlates with computed tomographic findings and predicts severe COVID-19 early. J Med Virol. 2020;92(7):85662. https://doi.org/10.1002/jmv.25871 PMid:32281668

11. Hou H, Zhang B, Huang H, Luo Y, Wu S, Tang G, et al. Using $\mathrm{IL}-2 \mathrm{R} / \mathrm{lym}$ phocytes for predicting the clinical progression of patients with COVID-19. Clin Exp Immunol. 2020;201(1):76-84. https://doi.org/10.1111/cei.13450

PMid:32365221

12. Sabogal Piñeros YS, Bal SM, Dijkhuis A, Majoor CJ, Dierdorp BS, Dekker T, et al. Eosinophils capture viruses, a capacity that is defective in asthma. Allergy. 2019;74(10):1898-909. https://doi. org/10.1111/all.13802

PMid:30934128

13. Percopo CM, Dyer KD, Ochkur SI, Luo JL, Fischer ER, Lee JJ, et al. Activated mouse eosinophils protect against lethal respiratory virus infection. Blood. 2014;123(5):743-52. https:// doi.org/10.1182/blood-2013-05-502443

PMid:24297871 
14. Samarasinghe $\mathrm{AE}$, Melo RC, Duan S, LeMessurier KS, Liedmann S, Surman SL, et al. Eosinophils promote antiviral immunity in mice infected with influenza A virus. The J Immunol. 2017;198(8):3214-26. https://doi.org/10.4049/ jimmunol.1600787 PMid:28283567

15. Yu P, Xu Y, Deng W, Bao L, Huang L, Xu Y, et al. Comparative pathology of rhesus macaque and common marmoset animal models with Middle East respiratory syndrome coronavirus. PLoS One. 2017;12(2):e0172093. https://doi.org/10.1371/ journal.pone.0172093

PMid:28234937

16. Zhang JJ, Dong $X$, Cao YY, Yuan YD, Yang YB, Yan YQ, et al. Clinical characteristics of 140 patients infected with SARSCoV-2 in Wuhan, China. Allergy. 2020;75(7):1730-41. https:// doi.org/10.1111/all.14238 PMid:32077115

17. Yun $\mathrm{H}$, Sun Z, Wu J, Tang A, Hu M, Xiang Z. Laboratory data analysis of novel coronavirus (COVID-19) screening in 2510 patients. Clin Chim Acta. 2020;507:94-7. https://doi. org/10.1016/j.cca.2020.04.018

PMid:32315614

18. Xie G, Ding F, Han L, Yin D, Lu H, Zhang M. The role of peripheral blood eosinophil counts in COVID-19 patients. Allergy. 2021;76(2):471-82. https://doi.org/10.1111/all.14465 PMid:32562554

19. World Health Organization. Clinical Management of Severe Acute Respiratory Infection (SARI) when COVID-19 Disease is Suspected: Interim Guidance. Geneva: World Health Organization; 2020. https://doi.org/10.15557/pimr.2020.0003

20. Yan B, Yang J, Xie Y, Tang X. Relationship between blood eosinophil levels and COVID-19 mortality. World Allergy Organ J. 2021;14(3):100521. https://doi.org/10.1016/j. waojou.2021.100521

PMid:33589865

21. Mu T, Yi Z, Wang M, Wang J, Zhang $\mathrm{C}$, Chen $\mathrm{H}$, et al. Expression of eosinophil in peripheral blood of patients with COVID-19 and its clinical significance. J Clin Lab Anal. 2021;35(1):e23620. https://doi.org/10.1002/jcla.23620

PMid:33118666

22. Domachowske JB, Rosenberg HF. Eosinophils, eosinophi ribonucleases, and their role in host defense against respiratory virus pathogens. J Leukoc Biol. 2001;70(5):691-8.

PMid:11698487

23. Yasui F, Kai C, Kitabatake M, Inoue S, Yoneda M, Yokochi S, et al. Prior immunization with severe acute respiratory syndrome (SARS)-associated coronavirus (SARS-CoV) nucleocapsid protein causes severe pneumonia in mice infected with SARSCoV. J Immunol. 2008;181(9):6337-48. https://doi.org/10.4049/ jimmunol.181.9.6337

PMid:18941225

24. Jiang S, Liu T, Hu Y, Li R, Di X, Jin X, et al. Efficacy and safety of glucocorticoids in the treatment of severe community-acquired pneumonia: A meta-analysis. Medicine. 2019;98(26):e16239. https://doi.org/10.1097/md.0000000000016239

PMID:31261585

25. Fulkerson PC, Rothenberg ME. Targeting eosinophils in allergy, inflammation and beyond. Nat Rev Drug Discov. 2013;12(2):11729. https://doi.org/10.1038/nrd3838

PMid:23334207

26. Cottin V. Eosinophilic lung diseases. Clin Chest Med. 2016;37(3):535-56. https://doi.org/10.1016/j.ccm.2016.04.015 PMid:27514599

27. Huang J, Zhang Z, Liu S, Gong C, Chen L, Ai G, et al. Absolute eosinophil count predicts intensive care unit transfer among elderly COVID-19 patients from general isolation wards. Front Med. 2020;7:585222. https://doi.org/10.3389/ fmed.2020.585222

PMid:33251234

28. Shaaban H, Daniel S, Sison R, Slim J, Perez G. Eosinopenia: is it a good marker of sepsis in comparison to procalcitonin and C-reactive protein levels for patients admitted to a critical care unit in an urban hospital? J Crit Care. 2010;25(4):570-5. https:// doi.org/10.1016/j.jcrc.2010.03.002

PMid:20435431 